\title{
Invención y realidad. La noción de mímesis como imitación creadora en Paul Ricœur
}

\author{
AlFREdo MARTÍNEZ SÁNCHEZ \\ Departamento de Filosofía \\ Universidad de Málaga \\ alms22@hotmail.com
}

\begin{abstract}
Resumen: Muchas de las propuestas de Ricœur en torno a la literatura, extensibles frecuentemente a sus tesis sobre el lenguaje en general, o dependientes de ellas, tienen su núcleo en una noción de mímesis originada en la Poética de Aristóteles. No se trata sólo de ideas afines a una teoría de la literatura o a una filosofía del lenguaje, sino que se adentran profundamente en el conjunto de su pensamiento, estableciendo vínculos entre distintos planos y cuestiones, que pueden conducir a una reflexión ética, apuntar el camino de una ontología, o desplegar un horizonte hermenéutico. Trataré de reconstruir la concepción de mímesis en Ricœur, preguntándome por su alcance, su significado y sus limitaciones.
\end{abstract}

Palabras clave: hermenéutica, literatura, estética, Aristóteles

\begin{abstract}
Many of Ricœur's proposals concerning literature, frequently extensible to his theses on language in general, or depending on them, have its core in a notion of mimesis originated in Aristotle's Poetics. It is not just a question of ideas related to a literary theory or to a philosophy of language, but they enter deeply into the whole of his thought, establishing links between different level and questions, which can lead to an ethical reflection, aim at the way of an ontology, or open a hermeneutic horizon. I will try to reconstruct the conception of the mimesis in Ricœur, wondering about its scope, its meaning and its limitations.
\end{abstract}

Key words: hermeneutics, literature, aesthetic, Aristotle

La tensión de la mímesis: invención (ficción) y realidad

La interpretación ricœuriana de la mímesis surge en el contexto de una teoría de la metáfora, de modo que, como veremos, toda mímesis tendrá algo de metáfora y toda metáfora será en alguna medida mimética. La recuperación de la mímesis aristotélica ${ }^{1}$ parte del rechazo de la interpretación de la mímesis como mera copia, comenzando por la identificación de aquellos rasgos que la separan de ésta. En primer

${ }^{1}$ Tomamos como punto de referencia inicial la obra de 1975 La metáfora viva [edición en castellano de 1980]. Ya desde su comienzo esta recuperación se sitúa, explícitamente, bajo la conciencia de la distinción contemporánea entre arte figurativo y no figurativo (véase La metáfora viva (1980), p. 60; las referencias bibliográficas completas se encuentran en la bibliografía). 
lugar, Ricœur señala las diferencias entre el concepto platónico y el aristotélico. Platón no sólo aplica la mímesis a todas las artes, sino a las cosas en su conjunto, designando diversos grados de semejanza, mientras que Aristóteles limita su empleo a las ciencias poéticas, excluyendo por tanto las teóricas y las prácticas. Por otra parte, lo que caracteriza a la mímesis aristotélica no es la relación de semejanza (como en la mímesis-copia), sino un proceso de construcción, la construcción de la trama, del mythos. ${ }^{2}$ La mímesis como proceso de construcción opone al carácter pasivo de la noción de copia el significado dinámico de la poiesis, que además la sitúa en el ámbito de la praxis: "3o cabe mímesis más que donde hay un hacer" (Ricœur 1980, p. 61). Como se verá en Tiempo y narración, el mythos, al igual que la mímesis, no son entendidos como estructura, sino como "operación" (Ricœur 1987a, p. 83). Desde el primer momento, Ricœur advierte el aspecto paradójico de la concepción aristotélica que vincula mímesis y poiesis: ${ }^{4}$ "iCuriosa imitación, la que compone y construye aquello mismo que imita!" (Ricœur 1980, p. 62). Imitar, en este sentido, no es duplicar la realidad, sino recomponerla, rehacerla, de modo que la cercanía a la realidad humana, que es lo imitado, se une a la distancia impuesta por la construcción de la trama. La dialéctica cercanía/distancia, que expresa la paradoja de la mímesis, nos ofrece la mejor perspectiva para entender la propuesta ricœuriana, en tanto que la cercanía indica la dimensión referencial y la distancia el momento de la invención-ficción.

\footnotetext{
${ }^{2}$ Aquí podemos apreciar cómo el autor tiende a reducir la mímesis aristotélica, en general, a la mímesis trágica. Según Aristóteles, mythos es una de las seis partes de la tragedia, y consiste en "la estructuración de los acontecimientos" (véase Ricœur 1980, p. 57). Aristóteles escribe: "llamo aquí fábula [mythos] a la composición de los hechos [synthesin]", y añade: "El más importante de estos elementos [de la tragedia] es la estructuración de los hechos [systasis]; porque la tragedia es imitación, no de personas, sino de una acción y de una vida" (Poética, 1450a4-5 y 15-17; traducción de Valentín García Yebra). Por otro lado, todos los elementos del poema trágico pueden ser considerados como factores de la mímesis, en la medida en que participan del principio de orden y construcción (cfr. Ricœur 1980, p. 62). Ricœur suele traducir mythos por "intrigue" (trama); obsérvese que asimila mythos y "synthesin" o "systasis" (es decir, mythos y "mise en intrigue" — "construcción de la trama" en la traducción castellana-; véase Tiempo y narración I (1987a)).

${ }^{3}$ La relevancia de la acción se observa también en que aparece de dos formas en la concepción aristotélica: como lo que es imitado y como lo que es compuesto o construido.

${ }^{4}$ Sobre el reconocimiento en otros autores de la unión aristotélica de creación e imitación, véase Ricœur 1980, n. 57, n. 59, p. 60 y n. 61, p. 61. Ricœur sigue interpretaciones de Richard McKeon, Leon Golden y O.B. Hardison.
}

Diánoia, vol. LI, no. 57 (noviembre 2006). 
En estas páginas de La metáfora viva se manifiesta el que podría ser identificado como origen del interés esencial de Ricœur por la mímesis: la capacidad del lenguaje para ir más allá de sí mismo, y especialmente la dimensión ontológico-referencial del lenguaje literario (por otra parte, defendido en numerosos lugares de su obra), de ahí que una cuestión fundamental en este libro sea la referencia metafórica. ${ }^{5}$ En estas mismas páginas de la sección 5 del primer estudio (consagrado a la retórica y a la poética de Aristóteles) se producen decisiones exegéticas que van a marcar el conjunto de la interpretación ricœuriana de la mímesis aristotélica: entre el mythos y la tragedia hay una "relación de esencia" (y no sólo de medio a fin o de causa natural a efecto); además, "el rasgo fundamental del 'mythos' es su carácter de orden" (Ricœur 1980, p. 58), lo que viene a confluir en uno de los dos rasgos que retiene de la mímesis: la idea de que "el 'mythos' es la mímesis. Más exactamente, la 'construcción' del mito constituye la mímesis" (Ricœur 1980, p. 62). Por último, el segundo rasgo que el autor retiene en interés de su investigación es la idea de elevación, lo que supone una reducción de la mímesis a mímesis trágica: "El segundo rasgo que interesa a nuestra investigación se enuncia así: en la tragedia, a diferencia de la comedia, la imitación de las acciones humanas es una imitación que enaltece. Esta peculiaridad es la clave para entender la función de la metáfora" (Ricœur 1980, p. 63). ${ }^{7}$

${ }^{5}$ Hacia el final del estudio afirma: "La verdad de lo imaginario, el poder de detección ontológica de la poesía, es precisamente lo que yo veo en la mímesis de Aristóteles" (Ricœur 1980, p. 68).

${ }^{6} \mathrm{El}$ autor interpreta desde esta perspectiva la afirmación aristotélica de que la poesía es más filosófica que la historia, así como la analogía entre el placer de la imitación y el placer del aprender. Al parecer, es "la función de orden" la que explicaría que la poesía se eleve a lo universal, y la que conecta mímesis y aprendizaje mediante "esa especie de clarificación, de transparencia total, que proporciona la composición trágica" (La metáfora viva, pp. 62 y 63). Pero, como se verá en Tiempo y narración, la función de orden, entendida como principio configurador, es compartida por el relato histórico y el de ficción.

${ }^{7}$ Ricœur cita el conocido texto de la Poética que distingue la imitación cómica de la trágica en este punto: "Y la misma diferencia separa también a la tragedia de la comedia; ésta, en efecto, tiende a imitarlos peores, y aquella, mejores que los hombres reales" (1448a 17-18); pero poco antes Aristóteles admite la diversidad de imitaciones como algo característico de la mímesis, sin reducirla al modelo trágico: "Más, puesto que los que imitan imitan a hombres que actúan, y éstos necesariamente serán esforzados o de baja calidad [...], o bien los hacen mejores que solemos ser nosotros, o bien peores o incluso iguales, lo mismo que los pintores. Polignoto, en efecto, los pintaba mejores; Pausón, peores, y Dionisio, semejantes" (1448a 1-7). Y añade: "Pues también en la danza y en la música de flauta y en la 
La recomposición mimética, por tanto, posee en la tragedia un rasgo específico: es una imitación que enaltece, realza o eleva aquello que imita, por esta vía la estructura de la mímesis coincide con la de la metáfora, ya que en ella también se da la unión de la recomposición con la elevación, y de la apelación a lo real (cercanía) con la invención (distancia). La combinación de estos elementos y la tensión que implica definen la función referencial de la metáfora. ${ }^{8}$ La elevación que Aristóteles aplicaba a la tragedia es comprendida por Ricœur como elevación de sentido, que es, a su vez, asimilada al desplazamiento de sentido propio de la metáfora, de manera que la mímesis es interpretada desde la metáfora y la metáfora desde la mímesis. ${ }^{9}$ Se establece así un paralelismo entre la metáfora y el mythos, o trama, de manera que el desplazamiento de sentido constitutivo de la metáfora es visto como la elevación de sentido operada por la mímesis mediante la construcción de la trama. El paralelismo se hace extensivo a la "katharsis", considerada como una elevación del sentimiento. ${ }^{10}$

La interpretación de la mímesis creadora puede encontrar un obstáculo en la afirmación aristotélica de que el arte imita la naturaleza, en el hecho de que la mímesis es mimesis physeōs. Según Ricœur, esta expresión no supone una negación o una restricción de la función creadora de la mímesis, sino que su propósito es solamente distinguir lo poético de lo natural (y, a la vez, coordinarlos). Por otra parte, los griegos tienden a pensar la physis como algo vivo más que como algo inerte; tal vez por eso, opina el autor, es posible "la imitación de

de cítara pueden producirse estas desemejanzas" (1448a 9-10). El texto continúa señalando la misma diversidad en otros ejemplos de géneros o artes miméticos.

${ }^{8}$ La metáfora, "puesta en relación con la imitación de las mejores acciones, participa de la doble tensión que caracteriza a la imitación: sumisión a la realidad $e$ invención de la trama, restitución y elevación. Esta doble tensión constituye la función referencial de la metáfora en poesía" (Ricœur 1980, p. 64). En esta obra el autor pretende formular una "concepción tensional de la verdad metafórica" (p. 331, véase también la p. 334), que dé cuenta de la pretensión del enunciado metafórico de alcanzar de alguna forma la realidad (p. 333). La tensión entre cercanía y distancia reproduce la tensión esencial entre pertenencia y distanciación (véanse las pp. 424 y 425. Para el desarrollo de la dialéctica pertenencia/distanciación, cuyas implicaciones hermenéuticas no podemos tratar aquí, véase "La Fonction herméneutique de la distanciation", así como "Qu'est-ce qu'un texte" y "Herméneutique et critique des idéologies", todos ellos recogidos en Ricœur 1986).

${ }^{9} \mathrm{El}$ autor encuentra corroboración en Aristóteles, para quien la buena metáfora ha de unir lo extraño con lo noble, donde lo extraño equivaldría al desplazamiento de sentido y lo noble a la elevación.

${ }^{10}$ Véase Ricœur 1980, p. 65. Compárese esta noción de elevación de sentido con la de incremento icónico que mencionaremos más adelante.

Diánoia, vol. LI, no. 57 (noviembre 2006). 
la naturaleza mediante la composición y la creación" (Ricœur 1980, p. 68). ${ }^{11}$

En la composición de la trama, la naturaleza imitada es la acción humana. La relación mimética entre el arte y la naturaleza, entre el poema trágico y la acción, no socava la autonomía del arte, ni lo reduce a mera copia, sino que establece su dimensión referencial (la mímesis garantiza que el mythos nos hable de la realidad). La referencia ha de ser aquí entendida en el sentido de nuestra pertenencia al mundo: el ser en el mundo es el horizonte de toda mímesis, especialmente en su significado dinámico y creativo. Esta mímesis desvela la capacidad cognoscitiva de la imaginación e introduce una forma de verdad en la poesía como poder de detección ontológica, como revelación de lo real, de manera que al ver-como del enunciado metafórico corresponde un ser-como en el orden extralingüístico. La noción de mímesis implica así una teoría de la verdad, que inicialmente se plantea como verdad metafórica, y se aparta de la concepción de la verdad-adecuación propia de la noción de representación. ${ }^{12}$

${ }^{11}$ Podríamos añadir que no sólo se trata de comparar lo natural con lo poético, sino con todo lo que comprende el término griego que traducimos como "arte": techné. Por otra parte, la interpretación de la afirmación aristotélica en términos de una estética realista resulta hoy anacrónica, es decir, no se trata de "reproducir" las cosas o los objetos naturales, sino más bien el modo de "producir" de la naturaleza (la analogía entre arte y naturaleza ha dado lugar históricamente a diferentes concepciones). Aubenque, a quien Ricœur remite (n. 70, p. 67), entiende que el arte viene a completar la naturaleza. Finalmente, el autor propone "una reactivación de su sentido en un contexto contemporáneo" al vincular la función referencial del discurso poético a la revelación de lo Real como Acto (aunque Ricœur envía al estudio VIII, allí tampoco dilucidará completamente esta idea). Ricœur no explota aquí la versión probablemente más coherente con el resto de su obra: el arte es como la naturaleza en cuanto a su poder creador, de crear mundo y de hacer mundo, y de permitirnos acceder a mundos posibles.

${ }^{12}$ En su artículo "Mimesis et représentation" (1982), Ricœur distingue entre ambos conceptos y señala la dimensión ilusoria de la representación, pero con la intención de recuperar parcialmente su sentido a través del concepto de mímesis, que encuentra rico en polisemia (en ocasiones incluso utiliza mímesis y representación como sinónimos). Véase 1982, pp. 51-53.

La noción de representación desempeña un papel fundamental en la investigación ricœuriana sobre la historia, si bien distingue entre "representación" y "representancia", entendida ésta en términos de "delegación" (véanse 1999a, pp. 81-82; 1996a, y 2003), donde se distingue entre representación-objeto y representaciónoperación. En esta obra se propone la denominación de "historia de las representaciones" para lo que frecuentemente se ha llamado "historia de las mentalidades", y se recupera la noción de representancia ("la capacidad del discurso histórico para representar el pasado" (2003, p. 315); véanse también las pp. 366-376). 
La referencia en la mímesis creadora

Si la mímesis es invención, no puede referirse al mundo como si lo representara en términos de copia. ${ }^{13} \mathrm{El}$ problema de fondo es, en general, el de la referencia de la ficción, y específicamente de la referencia literaria. La respuesta de Ricœur está ya apuntada en las líneas anteriores: la referencia se sitúa en el plano de nuestro ser en el mundo.

La concepción desarrollada por el autor supone, en primer lugar, pasar al nivel superior del texto, lo que en su opinión constituye la transición de la semántica a la hermenéutica, en el sentido de interpretación ejercida sobre el texto como obra: ${ }^{14}$ "La hermenéutica no es otra cosa que la teoría que regula la transición de la estructura de la obra al mundo de la obra. Interpretar una obra es desplegar el mundo de su referencia en virtud de su disposición, de su género, y de su estilo" (Ricœur 1980, p. 298). La cuestión de la referencia da un giro esencial cuando pasamos del plano de la palabra o de la frase al del texto y la obra, ya que es sólo entonces cuando podemos hablar de la referencia en términos de mundo, entonces la semántica resulta insuficiente y accedemos a la hermenéutica.

El interés hermenéutico por la referencia se ilumina retrospectivamente en nuestro autor en el contexto de sus diferencias con las tendencias estructuralistas que protagonizaron, en gran medida, el escenario cultural francés durante los años sesenta. Si bien su intención no era oponer hermenéutica y estructuralismo (más bien lo incorporó en cierto modo en su articulación de explicación y comprensión), ya señalaba que, frente a la lingüística, "en hermenéutica no hay clausura de los signos". ${ }^{15}$ Del mismo modo, en el artículo "Mimesis et représentation" (1982), la tarea hermenéutica contrasta con la empresa semiótica (en especial la de Greimas) al rebasar el aislamiento del texto, la específica

\footnotetext{
13 “Es preciso restituir a la hermosa palabra 'invención' su propio sentido desdoblado, que implica a la vez descubrir y crear" (1980, p. 413).

${ }^{14}$ Por texto Ricœur entiende no sólo la escritura, sino la producción del discurso como obra, cuyas categorías propias son la disposición, la pertenencia a géneros y la realización en un estilo singular. Como veremos, contempla la referencia metafórica en términos de redescripción de la realidad cuando pasamos del nivel de la frase al nivel del discurso - poema, relato, etc.— (véase 1980, pp. 14 y 296-297). Estas ideas serán desarrolladas en varios artículos, como los recogidos en Ricœur 1986.

15 "Le Problème du double sens", en Ricœur 1969, p. 67 (véase ahí también "La Structure, le mot, l'événement”, pp. 80-97, donde señalaba que lo esencial del lenguaje comienza más allá de la clausura de los signos).
}

Diánoia, vol. LI, no. 57 (noviembre 2006). 
configuración textual, que se corresponde con lo que Ricœur va a llamar mímesis II. ${ }^{16}$

Se ha de distinguir entre dos tipos de referencia: la del discurso descriptivo (que equivaldría a la de la mímesis como copia) y la de la obra literaria; pues bien, la segunda sólo emerge (la obra sólo despliega un mundo) a condición de que se suspenda la primera. Una referencia de segundo grado se despliega sobre la suspensión de la referencia de primer grado. En La metáfora viva, la referencia de segundo grado se identifica con la referencia metafórica, pero aunque el interés del autor se focaliza en la metáfora, también se indica que es el tipo de referencia propio de cualquier obra literaria. Esta idea será desarrollada y aplicada en trabajos casi contemporáneos, como "La fonction herméneutique de la distanciation" y "L'Imagination dans le discours et dans l'action". ${ }^{17}$ En el primero se explicita la noción de mundo de la obra, aunque entonces se prefiere la expresión "mundo del texto". La referencia propia de las obras de ficción, de la poesía, de la literatura, alcanza la realidad de un modo específico distinto de la del lenguaje ordinario, descriptivo o científico, en el plano donde se situarían el mundo de la vida de Husserl o el ser-en-el-mundo de Heidegger. La abolición de la referencia de primer grado enfatiza aquí la ruptura que el texto supone con respecto al entorno del discurso oral, y surge, de esta manera, el mundo del texto, que el autor entiende como una proposición de mundo, como un mundo virtual que abre nuevas posibilidades de ser-en-el-mundo. Es esa proposición, precisamente, la que constituye el objeto de la interpretación, el objeto hermenéutico, lo que hay que interpretar en un texto. En Tiempo y narración I (1987a, p. 158) leemos: "He defendido continuamente estos últimos años que lo que se interpreta en un texto es la propuesta de un mundo en el que yo pudiera vivir y proyectar mis poderes más propios." 18

\footnotetext{
${ }^{16}$ Véase Ricœur 1982, p. 53.

${ }^{17}$ Publicados inicialmente en 1975 y 1976, y recogidos en Du texte à l'action, de donde serán citados. Véase también Teoría de la interpretación, que reproduce una serie de conferencias pronunciadas en Estados Unidos en 1973.

${ }^{18}$ Sobre el concepto de mundo, el autor hace en estas páginas una afirmación sorprendente por su rotundidad: "para mí, el mundo es el conjunto de las referencias abiertas por todo tipo de textos descriptivos o poéticos que he leído, interpretado y que me han gustado" (p. 157). Por otro lado, se señala que el problema planteado por la referencia narrativa es más sencillo y, a la vez, más complicado que el de la poesía lírica: más sencillo porque opera sobre la acción, más complicado por la existencia de dos grandes discursos narrativos con características específicas: la narración de ficción y la historiografía (véanse las pp. 158-160). Sobre la noción
} 
De algún modo, Ricœur escinde la realidad del receptor desde que distingue entre dos tipos de referencia (la del lenguaje cotidiano y descriptivo, y la del lenguaje poético o literario — eventualmente extensible al arte en su conjunto-): la realidad corriente y la realidad transfigurable y transfiguradora; en cierto sentido, la realidad superficial y la realidad profunda (por eso puede haber dicho que el mundo para él es el conjunto de referencias abiertas por los textos) — realidad de una mayor densidad ontológica-. Esta realidad es la que encontramos en su noción habitual de mundo, esta realidad es la recreada por la ficción, por el arte, y que en cierto modo es producida por éstos. Esta idea de producción, esencial en las nociones de mímesis y refiguración, quebranta la división ingenua o fácil entre realidad y ficción; sin embargo, ambas realidades se fusionan en el receptor de la obra, pues el mundo de su acción no se reduce a la realidad transfigurada, y la transfiguración acaba afectando a toda su realidad.

Antes de considerar el segundo de los artículos mencionados ("L'Imagination dans le discours et dans l'action"), regresemos a La metáfora viva.

La constitución mimética de metáforas y modelos

La noción de mímesis creadora surgida de la interpretación de la Poética aristotélica adquiere un grado mayor de elaboración mediante su paso por la teoría de los modelos de Max Black y Mary Hesse ${ }^{19}$ (así como por la inspiración recibida de Nelson Goodman). ${ }^{20}$ Según esta teoría, la relación con lo real que establece la metáfora en el lenguaje poético es equivalente a la que mantiene el modelo en el lenguaje científico. ${ }^{21} \mathrm{La}$ expresión "redescripción" en este contexto proviene de M. Hesse, quien vincula el uso de los modelos al de la referencia metafórica. El modelo es un instrumento heurístico de redescripción; con él se pretende

de mundo, véase también Du texte à l'action, 1986, pp. 112-115, y "Poetry and Possibility" en Valdés 1991.

${ }^{19}$ Véase Ricœur 1980, pp. 323-332.

${ }^{20}$ Especialmente la idea de que la poesía, en cuanto sistema simbólico, implica una función referencial, y la capacidad de los sistemas simbólicos para rehacer el mundo. Ricœur reproduce con gusto la afirmación de Goodman de que la actitud estética "es menos actitud que acción: creación y re-creación" (véase Ricœur 1980, pp. 311 y 321 ; si bien se distancia en algunos puntos: véanse las pp. 313 y 322).

${ }^{21} \mathrm{El}$ equivalente exacto no sería tanto una metáfora aislada como una red metafórica, ya que el modelo consiste en una red de enunciados. La función referencial de la metáfora depende más bien de una red que de un enunciado metafórico aislado. 
encontrar, mediante la ficción, una descripción mejor, romper una interpretación inadecuada y abrir paso a otra, pero esta redescripción es una "redescripción metafórica". ${ }^{22}$ La relación que en la teoría de los modelos se da entre la ficción heurística y la redescripción equivale a la que se produce entre mythos y mímesis en la poiesis clásica. A partir de este momento, Ricœur va a entender la mímesis en términos de redescripción, concepto que reúne los dos elementos que le preocupan: el heurístico (o creativo) y el referencial (o denotativo). La redescripción se propone así como la alternativa pertinente a la concepción de la mímesis como simple copia. ${ }^{23}$

Con estas mediaciones, el concepto de mímesis creadora logra una mayor determinación y a la vez se amplía, de este modo supera también los límites de la poesía trágica (superación que ya se estaba produciendo implícitamente por otro camino al elaborar la teoría de la referencia literaria que hemos visto antes). En la lírica, el lugar del mythos es ocupado por lo que el autor denomina con un término inglés: mood. ${ }^{24} \mathrm{El} \mathrm{mood} \mathrm{es} \mathrm{el} \mathrm{sentimiento} \mathrm{articulado} \mathrm{por} \mathrm{el} \mathrm{poema;} \mathrm{en}$ La metáfora viva es introducido para completar la teoría de la mímesis. Se trata, pues, de justificar que la unión entre mythos y mímesis no se da sólo en la poesía trágica: "La unión entre 'mythos' y mímesis actúa en toda poesía" ${ }^{25}$ (examinaremos cómo esta conexión se aplica también al

${ }^{22}$ Ricœur 1980, p. 326. Ya en el Estudio primero Ricœur introduce la dimensión cognoscitiva de la metáfora (apuntada por Aristóteles en la Retórica cuando afirma que nos instruye y nos enseña), anunciando el concepto de redescripción: "La relación establecida por Max Black entre modelo y metáfora, es decir, entre un concepto epistemológico y un concepto poético, nos permitirá explorar a fondo esta idea que se opone frontalmente a cualquier reducción de la metáfora a un simple 'adorno'. Si llegamos hasta el fondo de esta sugerencia, hay que decir que la metáfora comporta una información porque 're-describe' la realidad' (p. 37).

23 "En cuanto a la mímesis, deja de crear dificultades y causar escándalo cuando ya no se entiende en términos de copia, sino de redescripción" (Ricœur 1980, p. 329).

${ }^{24}$ El uso que Ricœur hace de esta expresión tiene su origen en Northrop Frye, si bien el autor encuentra en ella un alcance no reconocido por el crítico canadiense. El mood aparece como un "valor afectivo" articulado por la estructura del poema; pero, según Ricœur, "este 'modo' es mucho más que una emoción subjetiva, es un modo de enraizarse en la realidad, es un componente ontológico" (Ricœur 1980, p. 205). Véanse, también, las pp. 305 y 309, donde vemos que, para Frye, mood se entiende como un "estado del alma" identificado con el poema mismo (el estado del alma es el poema).

${ }^{25}$ Ricœur 1980, p. 330. Sin embargo, en Aristóteles no es fácil integrar la poesía lírica en su concepción de la poesía como mímesis de acciones humanas; de ahí que en la Poética predomine el género dramático, específicamente la tragedia, y 
relato). El mood es una especie de mythos lírico en la medida en que, como hemos visto, ocupa en la poesía lírica el lugar que el mythos tiene en la tragedia, y en la medida en que "el sentimiento articulado por el poema no es menos heurístico que la trama trágica" (Ricœur 1980, p. 330). El mood es también, por tanto, una especie de modelo para "ver como" y "sentir como"; el sentimiento posee una función ontológicoreferencial, ya que al ser transformado en realidad literaria es capaz de abrir y descubrir mundo. ${ }^{26}$ Precisamente el proceso de construcción del mood, al igual que el proceso de construcción de la trama y del modelo, es la condición de la función mimética. El mundo, en un sentido no cosmológico, es abierto y descubierto mediante un proceso que paradójicamente implica también una distanciación con respecto a la realidad, distancia que no es sino la diferencia implicada por la propia naturaleza de la invención y de la ficción (la distancia se convierte en condición de la cercanía). ${ }^{27}$

Esta concepción de la referencia será integrada en una generalización de la fuerza heurística de la ficción dentro de una teoría de la imaginación en "L'Imagination dans le discours et dans l'action". ${ }^{28} \mathrm{~A}$ través de la referencia de segundo grado, la ficción provoca un efecto que no es sino la consecuencia de su poder de redescribir la realidad. Esta conexión entre ficción y redescripción, que proviene de la teoría de los modelos, pone de manifiesto la fuerza heurística de la ficción, consistente en su capacidad para abrir y desplegar nuevas dimensiones de realidad.

La noción de mímesis así elaborada presenta tres rasgos esenciales de la teoría literaria y la concepción estética de Ricœur:

a) La preocupación ontológico-referencial;

b) La función cognitiva del arte (próxima a la de N. Goodman);

c) El concepto de mundo o realidad (tal y como es revelado por la referencia de segundo grado y por la vinculación entre invención y descubrimiento). ${ }^{29}$

que ocupe un lugar inferior la épica y prácticamente no aparezca la tradición de la poesía lírica griega.

26 “Como sugiere la unión de ficción y redescripción, el sentimiento poético también desarrolla una experiencia de realidad en la que invención y descubrimiento dejan de oponerse, y en la que creación y revelación coinciden" (p. 332).

27 "La paradoja de lo poético reside totalmente en que la elevación del sentimiento a ficción es la condición de su despliegue mimético" (Ricœur 1980, p. 332).

${ }^{28}$ Ricœur 1986, pp. 213-236.

${ }^{29}$ La ontología de la referencia metafórica, y del lenguaje literario, se resuelve en 
Los tres se relacionan, a su vez, con una teoría de la verdad (metafórica).

\section{La transposición al relato}

La ampliación de la concepción de la mímesis ya se había iniciado al proponer la teoría de la referencia literaria, así como en la generalización de la fuerza heurística de la ficción. Pero su aplicación al campo narrativo será objeto de una articulación específica y de una elaboración que ocupa un lugar de especial relevancia en la obra de Ricœur. ${ }^{30}$

Aunque esta elaboración se realiza en la trilogía Tiempo y narración, comienza ya en la sección dedicada al simbolismo representativo ${ }^{31}$ en una publicación anterior: "La Structure symbolique de l'action". La narración se presenta como ejemplo de una categoría de símbolos representativos mediante el cual el autor pretende poner de manifiesto una función capital de la representación: "forjar ficciones con carácter heurístico" (Ricœur 1977, p. 46). La elección de la narración, como ejemplo para ilustrar esa característica de la representación, se basa en que la referencia de la narración es, precisamente, la acción humana (al pasar de la metáfora al relato se aprecia un nuevo énfasis en la acción). La tesis central consiste en que la narración redescribe la acción. Tratando de sistematizar las implicaciones de esta idea, distinguiremos, en primer lugar, que la narración se refiere a la acción; en segundo lugar, que la narración no reproduce simplemente la acción, sino que la rehace, tal y como pone de relieve la interpretación de la noción aristotélica de mímesis, y en tercer lugar, que esa redescripción de la acción tiene consecuencias que van más allá del mero ámbito lingüísti-

términos de exploración y tentativa, como manifiesta el estilo interrogativo (véase 1980, pp. 299, 332, 411 y 416-417).

${ }^{30}$ Ir de la metáfora al relato es un ampliar o transponer el modelo de la mímesis pero también un regresar al paradigma original, aristotélico, que está más cerca de la mímesis de acciones (del teatro y de la narración) que de la poesía en sentido moderno (lírica). Por otra parte, la universalización del modelo estaba ya produciéndose implícitamente cuando la función mimética se vincula a la metáfora, ya que ésta no es exclusiva de la poesía, sino que también se da, entre otros géneros, en el relato, y sobre todo porque la referencia metafórica proporciona un paradigma de la comprensión ricœuriana de todo texto literario, incoativamente ampliable al ámbito de la ficción en su conjunto.

${ }^{31}$ La distinción entre simbolismo constituyente y simbolismo representativo, que se hace en "La Structure symbolique de l'action" (pp. 32 y 33), será sustituida por la distinción entre simbolismo implícito o inmanente y simbolismo explícito o autónomo (Ricœur 1987a, p. 124). 
co, hasta lo que el autor llama con frecuencia mundo de la acción (este último aspecto será estudiado en Tiempo y narración bajo el título de "Mímesis III").

La posibilidad de forjar ficciones de carácter heurístico depende, precisamente, de la capacidad de la narración para redefinir la acción, capacidad que, a su vez, se encuadra dentro de la relación referencial que se establece entre el texto y la acción.

La tercera parte de Tiempo y narración, contenida en el segundo volumen, se ocupa de "ensanchar, profundizar, enriquecer y abrir hacia el exterior la noción de construcción de la trama recibida de la tradición aristotélica". ${ }^{32}$ De estas tareas, la primera es la que se ocupa directamente de justificar la utilización del modelo aristotélico más allá de su ámbito original hasta un determinado conjunto de géneros literarios, y especialmente con respecto a la novela. ${ }^{33}$ Se analiza, en primer lugar, el impacto de distintas formas de novela sobre la noción de trama y sobre su construcción. Por una parte, podemos considerar la noción de carácter, que evoluciona desde la novela picaresca hacia la novela educativa, y finalmente parece destruir la trama misma en la novela del flujo de conciencia (ilustrada aquí por Virginia Woolf). La respuesta de Ricœur pasa por una interpretación amplia del concepto de acción paralela a una ampliación del concepto de trama: "También es acción, en un sentido amplio, la transformación moral de un personaje", así como "los cambios puramente interiores" (Ricœur 1987b, p. 26). De modo que

La novela moderna nos enseña a alargar la noción de acción imitada (o representada) tanto como podemos decir que un principio formal de composición vela por la estructuración de los cambios capaces de afectar a seres semejantes a nosotros [...], seres incluso hasta sin nombre, como en Beckett. (Ricœur 1987b, p. 27)

${ }^{32}$ Ricœur 1987b, p. 16 La búsqueda de un metagénero narrativo pasa por la generalización del concepto de trama, que tiene su eje en la configuración narrativa (a veces designada como actividad configurante) que equivale a la construcción de la trama; esto significa que la raíz de la idea de trama es el principio de orden (que como vimos era considerado el rasgo fundamental del mythos en La metáfora viva). Así, toda la apuesta que abre Tiempo y narración II se centra en la posibilidad de ampliar "la noción de construcción de la trama heredada de la tradición aristotélica". De esta manera, la continuidad con el mythos trágico se juega en la noción de los principios formales de discordancia-discordante y síntesis de lo heterogéneo que determinan el concepto de trama (véase Ricœur 1987b, pp. 16-22).

${ }^{33}$ En las "Conclusiones", el autor reflexiona sobre su empeño de agrupar bajo la noción de "relato de ficción" distintos géneros literarios convencionales, según el criterio de su común contribución a una "mímesis de la acción".

Diánoia, vol. LI, no. 57 (noviembre 2006). 
La crisis de la trama se manifiesta con más crudeza cuando se plantea el abandono del criterio de totalidad que pone en cuestión la propia noción de mythos. ${ }^{34}$ Volveremos sobre estas cuestiones en la sección sobre la reapropiación del modelo aristotélico.

\section{La triple mímesis}

Tiempo y narración se presenta como una obra gemela de La metáfora viva. La metáfora y la narración, a pesar de sus diferencias, comparten el hecho de que "los efectos de sentido producidos por ambas incumben al mismo fenómeno central de innovación semántica" (Ricœur 1987a, p. 33). En esta medida, Tiempo y narración prolonga la investigación en torno a la creación en el ámbito del lenguaje y a su eficacia extralingüística.

El concepto de mímesis reaparece como hilo conductor, aunque subordinado, de la pesquisa que dirige la trilogía: la relación entre Tiempo y narración. Vuelve a remitir a su origen aristotélico para proyectarse inmediatamente a nuevas significaciones. La función mimética de la narración es una aplicación particular de la referencia metafórica a la esfera del obrar humano, por tanto, la diferencia esencial entre Tiempo y narración y La metáfora viva no es sólo la transposición de la metáfora a la narración, sino también la mayor incidencia en la acción humana. Mientras que la redescripción metafórica se vincula a "los valores sensoriales, pasivos, estéticos y axiológicos", "la

${ }^{34}$ La argumentación gira en torno a la idea de fin como elemento que cierra la obra convirtiéndola en una totalidad, siguiendo de cerca los análisis de Frank Kermode. En última instancia, lo que supone la crisis de la trama es que "el autor, en lugar de abolir cualquier convención de composición, debe introducir nuevas convenciones más complejas, más sutiles, más encubiertas, más hábiles que las de la novela tradicional". "Es inimaginable —concluye el autor- que la narración pueda prescindir de toda configuración" (Ricœur 1987b, p. 51; véanse, también, las pp. 58 y 158). A este respecto podemos plantear las siguientes preguntas: ¿es la ausencia de toda configuración la que marca la ruptura con el modelo aristotélico?, o bien ¿es posible abandonar ese modelo antes de llegar al extremo de la disolución de la configuración?; es decir, ¿el hecho de que siempre deba haber configuración, aunque sea más compleja y sutil, garantiza la filiación aristotélica?

La unidad de acción es descrita y prescrita por Aristóteles en distintos momentos de la Poética; en relación con el mythos o la estructuración de los hechos afirma: "Hemos quedado en que la tragedia es imitación de una acción, completa y entera, de cierta magnitud [...]. Es entero lo que tiene principio, medio y fin." El fin es definido como "lo que por naturaleza sigue a otra cosa, o necesariamente o las más de las veces, y no es seguido por ninguna otra" (1450b24-30, pp. 152-153). La unidad y la totalidad están, además, vinculadas a la necesidad o verosimilitud. 
función mimética de las narraciones se manifiesta preferentemente en el campo de la acción y de sus valores temporales" (Ricœur 1987a, p. 35).

En una reflexión posterior, Ricœur señalará, además, que en La metáfora viva faltaba un eslabón intermedio entre el lenguaje y la realidad, que ya se encuentra en la trilogía dedicada al relato: la lectura. ${ }^{35}$ Desde este punto de vista, lo redescrito no es lo real sin más, sino la realidad que pertenece al mundo del lector, en el ámbito de lo que se caracterizará como mímesis III.

La preeminencia de la acción proviene del propio tratamiento aristotélico de la relación mímesis-mythos, ${ }^{36}$ así como la condición esencialmente dinámica y productiva de ésta, dando lugar, como hemos visto, a una idea de mímesis productiva: "La imitación o la representación es una actividad mimética en cuanto produce algo: precisamente, la disposición de los hechos mediante la construcción de la trama" (Ricœur 1987a, p. 88). A su vez, mediante la disposición de los hechos, se (re)-construye la acción. Pero la mímesis no se reduce a esta realización, que coincidirá, estrictamente, con lo que se va a llamar mímesis II (responsable de la autonomía semántica y de la intertextualidad), sino que Ricœur va a proponer una noción ampliada que la rebasa, tanto hacia delante como hacia atrás. La mímesis se estructura, a partir de ahora, en tres momentos, describiendo un arco mediante el que el texto se levanta sobre (remonta) la experiencia práctica, sobre el fondo de la vida, y retorna (desciende) a ella cuando llega al lector. Para la hermenéutica, el texto ha de entenderse en el proceso completo que describe esta trayectoria; la hermenéutica está comprometida con

${ }^{35}$ Véase Ricœur 1997, p. 50.

${ }^{36}$ Ricœur se remite a varios lugares de la Poética de Aristóteles, de entre los que destacan para la noción de mímesis 50a, 1 y 50b, 3. García Yebra, en su versión de la obra de Aristóteles, traduce mythos por "fábula", mientras que Ricœur lo hace por "intrigue" ("trama" en la edición española de Tiempo y narración) (véase la nota 2). En cuanto a "mímesis", García Yebra traduce "imitación”, y Ricœur acepta que se vierta por "imitation" o "représentation" (cfr. Ricœur 1987a, p. 86, y Aristóteles, Poética, pp. 146 y 150).

En la cita de 50a, 1: "C'est l'intrigue qui est la représentation de l'action" ("La trama es la representación de la acción”) (véase Ricœur 1987a, p. 88; parece existir un error, ya que la frase del texto aristotélico se encuentra en realidad en 50a4 (cfr., por ejemplo, la traducción de García Yebra, y la edición francesa a cargo de J. Hardy, Les Belles Letres, París, 1969).

En $D u$ texte à l'action (1986) aparece la referencia a la acción y la concepción de la mímesis también en otros contextos —el debate explicación/comprensión(véanse las pp. 168 y 175).

Diánoia, vol. LI, no. 57 (noviembre 2006). 
la unidad de la mímesis en un proceso global que comprende los tres momentos. ${ }^{37}$

De entrada, esta dilatación o descomposición de la mímesis suscita cierta perplejidad o al menos resulta inesperada. ¿Por qué seguir llamando mímesis a los estadios anterior y posterior a la expresa disposición de los hechos en la construcción textual de la trama, es decir, más allá de la propia invención-realización efectiva de la obra por parte de su autor? Probablemente el horizonte último en el que se integra la articulación de la triple mímesis es de carácter antropológico: la naturaleza temporal de la experiencia humana y su expresión narrativa. Más allá de este fondo de máxima generalidad y tratando de efectuar una aproximación más concreta sugeriré tres respuestas complementarias a las que añadiremos una cuarta expresamente desarrollada por Ricœur. Por un lado, tenemos el deseo del autor de enfatizar el aspecto referencial del lenguaje, su relación con la realidad ${ }^{38}$ (decisivo para la hermenéutica), pero esto es más una explicación que una justificación; intentaremos avanzar en esta última dirección. Así, la doble naturaleza del signo nos proporciona un nuevo argumento: el signo es una cosa o un objeto en sí mismo, pero existe para designar otra cosa u otro objeto distinto de él. Esta dualidad nos recuerda la dialéctica distan-

${ }^{37}$ Véase, por ejemplo, la conexión fundamental entre la unidad de la triple mímesis y la hermenéutica en "Mimesis et représentation", p. 53. Cfr. La metáfora viva, donde el acento se ponía en la cuestión de la referencia.

${ }^{38}$ No me he atrevido a escribir "realidad extralingüística", pues, si bien el mood es efectivamente una realidad extralingüística a la que se refiere la obra ("Con el nombre de mood se introduce un factor extralingüístico que, aunque no hay que tratarlo psicológicamente, es el indicio o síntoma de una manera de ser. Un estado del alma es una manera de encontrarse en medio de la realidad", Ricœur 1980, p. 309), ha de estar en la obra ("la obra se refiere a una emoción que desapareció como emoción, pero que se ha conservado en la obra", Valdés 2000, p. 164). Por otra parte, el mundo del texto o de la obra por el que se define la referencia de segundo grado ¿hasta qué punto es un mundo extralingüístico en un sentido último?, no es mero signo en sí, pero tampoco es la realidad a la que se refiere el lenguaje cotidiano. El mundo del texto alude a la suerte de ser en el mundo desplegado ante el texto, y cada texto tiene su propio mundo singular (véase Ricœur 1986, pp. 114 y 115). Quizá deberíamos distinguir entre extratextual y extralingüístico, en la medida en que lo lingüístico no se acaba en el texto. En cualquier caso, puede apreciarse en Ricœur una evolución: en La metáfora viva el lenguaje actúa sobre la realidad (en una interpretación ontológico-referencial) de un modo más directo, mientras que en obras posteriores, como ya hemos adelantado, esta relación se produce por medio del mundo del lector. El capítulo 4 de la segunda sección de Tiempo y narración III está dedicado al encuentro entre el mundo del texto y el mundo del lector, explorando particularmente su aspecto retórico. 
cia/cercanía que caracterizaba la función mimética de la metáfora, e ilumina también la relación entre configuración y refiguración, pues la configuración se corresponde con la primera vertiente del signo (como retirada a su propio orden), y la refiguración con la segunda (como regreso al mundo). ${ }^{39}$ La triple articulación de la mímesis encuentra soporte, además, en la propia acción en virtud de su pertenencia, tanto al ámbito de lo imaginario, como al de lo real, la acción construida que emerge en mímesis II, y la acción de la que emerge y a la que regresa en mímesis I y mímesis III. Efectivamente, hay, como ya hemos adelantado, una acción construida en el texto (análoga a la primera función del signo), y, por otra parte, una acción que es el correlato extralingüístico de aquélla (análoga a la segunda función), pero es que, además, el mismo proceso de construcción de la trama es ya, también, una acción, un hacer. ${ }^{40}$ Esta pertenencia garantiza cierta continuidad entre los dos dominios, el imaginario y el real, que permite conectar los tres momentos de la mímesis y nos da la clave del lazo infrangible, la permanente comunicación, entre narración (ficción, arte) y realidad -entendida ahora fundamentalmente en un sentido práctico- - Es la acción (y, en última instancia, la dimensión referencial del lenguaje) la que proporciona unidad a la triple mímesis, que se descompone en prefiguración (mímesis I), configuración (mímesis II), y refiguración (mímesis III). La primera designa las condiciones prácticas y temporales que hacen posible la narración de la acción o la construcción de la trama, que constituye propiamente el momento de la configuración, mientras que la refiguración designa el encuentro entre el mundo de la obra y el mundo del lector a través de la lectura: "Lo que está en juego, pues, es el proceso concreto por el que la configuración textual media entre la prefiguración del campo práctico y su refiguración por la recepción de la obra" (Ricœur 1987a, p. 118). La lectura es ese tejido

39 "Por una parte, el signo no es la cosa, está retirado (en retrait) de ésta, y por ello engendra un nuevo orden que se dirige a una intertextualidad. Por otra parte, el signo designa algo, y hay que prestar mucha atención a esta segunda función, que interviene como una compensación con respecto a la primera, pues compensa el exilio del signo en su propio orden" (Valdés 2000, p. 157). La doble condición del signo no se limita al plano lingüístico, mientras que el dominio de la acción parece insertarse en la esfera de la narración (en el sentido amplio que Ricœur le concede). Como veremos, el autor generalizará, aunque no de un modo sistemático, el principio mimético al arte en su conjunto, y particularmente en un ámbito que compartirían la literatura, las artes plásticas y la música (véase Valdés 2000, pp. 158, 160 y 161).

${ }^{40}$ Lo que ya estaría en la concepción aristotélica (véase "Mimesis et représentation", pp. 51 y 52).

Diánoia, vol. LI, no. 57 (noviembre 2006). 
en el que el lenguaje y la realidad se cruzan para proyectarse, esta vez sí, más allá del texto mediante la refiguración. ${ }^{41}$

Lo que se prefigura, configura y refigura es tanto el tiempo, como la acción. Inicialmente, y ya desde el título de la obra que ahora nos ocupa, Tiempo y narración, el tiempo parece tener la preeminencia, pero no es exactamente así, ya que el tiempo es entendido, en la función mimética, como una propiedad práxica: es la acción en su conjunto, y particularmente el tiempo de la acción, lo que a través de la configuración será refigurado, de modo, que, en este punto, la cuestión del tiempo parece estar subsumida en la de la acción. ${ }^{42}$

La narración describe así un arco que se eleva sobre el plano del obrar (y del padecer) para acabar incidiendo sobre él. Mímesis III regresa a mímesis I a través de mímesis II, la mímesis describe un arco, un arco hermenéutico en la medida en que el paso de M-I a M-III no es redundante. ${ }^{43}$

El término mímesis solo puede ser mantenido a costa de una polisemia no suficientemente señalada; claro que hay elementos que vinculan cada uno de los tres momentos de la mímesis, pero, también, en cada uno de ellos mímesis significa algo distinto. Así, mímesis II y mímesis III, ambas rehacen la realidad pero en un sentido diferente; en la primera la realidad se rehace literariamente, en un texto, en el plano de la ficción; mientras que, en la segunda, la realidad que ha de rehacerse es extratextual, es la realidad efectiva del lector. En la expresión "rehacer la realidad", ni "rehacer" ni "realidad" significan lo mismo. En cuanto a mímesis I, tenemos que, por una parte, es la condición de

${ }^{41}$ La noción de refiguración resultará singularmente fecunda en la obra de Ricœur. El concepto de identidad narrativa, del que el autor se ha ocupado en varios lugares, aparece como resultado del proceso de refiguración, la identidad narrativa no es sino el efecto identitario del encuentro del mundo del lector con el mundo de la obra, el efecto de la narración sobre la identidad. La mímesis, y en especial la refiguración, justifican, por otra parte, la mediación narrativa entre describir y prescribir, facilitando el enlace hacia la ética, tal y como se muestra en Sí mismo como otro (1996b). Además, la relación mimética reaparece también en esa misma obra en el examen del nexo entre ficción/literatura y vida, en un momento reflexivo en el que el autor se interroga por las dificultades que implica el trayecto de retorno de la ficción a la vida según el proceso de refiguración (véanse las secciones "Entre describir y prescribir: narrar" y "Las implicaciones éticas del relato" en el Estudio sexto).

42 "En último término, es el tiempo de la acción el que realmente es refigurado por su representación" (Ricœur 1987a, p. 160).

${ }^{43}$ Acerca de una eventual circularidad de este arco, véase Ricœur 1996a, p. 286, n. 1, y p. 1000, así como Ricœur 1987a, pp. 148-150. 
posibilidad del resto del proceso, lo que hace posible rehacer, sería una premímesis en términos de precomprensión, el primer paso de un proceso de mayor alcance. Al mismo tiempo comprendemos nuestra vida de un modo narrativo; he aquí una primera mímesis como autocomprensión narrativa preliteraria; sin embargo, ¿cabe hablar de historias prenarrativas en este sentido, como lo hace Ricœur? ¿Existe alguna historia anterior a algún modo, por implícito o informal que sea, de narración? ${ }^{44}$

Veamos a continuación la estrategia justificadora de la unidad y articulación de la mímesis partiendo de su exposición en "Mimesis et représentation". ${ }^{45}$ Podemos identificar en la argumentación tres núcleos fundamentales:

1) Precomprensión. Hay una precompresión (previa a toda narración efectiva) común al autor y a su público, esta familiaridad es la que será transfigurada ${ }^{46}$ por medio de la ficción. ${ }^{47}$ A pesar de la ruptura que ella instituye (la "literariedad", en el sentido propuesto por el formalismo ruso), la ficción jamás sería comprensible si no viniera a configurar lo que la acción ya figura. No hay mímesis II sin esta precomprensión: por ello, la mímesis comienza con la precomprensión semántica (de la red semántico-conceptual), simbólica (en el sentido que tiene en Clifford Geertz) y temporal de la acción. ${ }^{48}$

Pero ¿por qué "mímesis"?, ¿por qué no utilizar otra palabra? Porque si mímesis es producir y es un proceso, la producción comienza en el carácter prenarrativo de la acción, en una precomprensión que establece un puente entre la acción efectiva y la acción narrada, en un plano en el que la acción se muestra capaz, susceptible de ser re-creada narrativamente.

${ }^{44}$ Sobre la estructura prenarrativa de la experiencia, véase Ricœur 1987a, pp. 145-151. Por otra parte, en Tiempo y narración III el autor distingue dos sentidos de lo narrativo: lo efectivamente narrado y lo virtualmente narrable (racontable) (véase Ricœur 1996a, p. 1017).

${ }^{45}$ La mayor parte de sus contenidos serán ampliados en el primer volumen de Tiempo y narración, que será oportunamente citado; pero en este artículo el problema de la articulación y la unidad de los tres momentos se establece explícitamente como la cuestión axial. En la trilogía la mímesis aparece al servicio de la mediación entre tiempo y narración.

${ }^{46}$ El término transfiguración que encontramos en "Mimesis et représentation" será sustituido a partir de Tiempo y narración por el de refiguración.

${ }^{47}$ Véase Ricœur 1982, p. 53.

${ }^{48}$ No se trata de una lista necesariamente cerrada, véase Ricœur 1987a, p. 120, y pp. 121-134.

Diánoia, vol. LI, no. 57 (noviembre 2006). 
Nos queda, finalmente, la insistente duda de si estos tres rasgos de la precomprensión práctica (semántico-conceptual, simbólico y temporal) podrían ser transferidos al ámbito de las artes plásticas mediante una ampliación del modelo narrativo.

2) Inteligibilidad. ${ }^{49}$ ¿Qué es lo que se imita, qué es lo que se produce? La construcción de la trama no es la mera reproducción de la acción, sino más bien una depuración inteligible; es esta inteligibilidad lo que es imitado. ${ }^{50}$ La posibilidad de recorrer como un único proceso los tres estadios de la mímesis depende, para Ricœur, de lo que signifique esta inteligibilidad (Ricœur 1982, p. 56).

Mientras que la semiótica opta por una lógica narrativa, una racionalidad de los códigos narrativos, Ricœur prefiere hablar de una inteligibilidad previa que depende tanto del remonte (de la vida al texto, es decir, de M-I a M-II) como del descenso (del texto a la vida, de M-II a M-III): esta inteligibilidad abarca los tres momentos de la mímesis, y se concreta en la capacidad para seguir una historia. No se trata de una simple oposición entre inteligencia narrativa y racionalidad narratológica, sino más bien de una complementariedad apropiadamente jerarquizada: la hermenéutica se pregunta por las condiciones de inteligibilidad de la racionalidad semiótica. La tesis de Ricœur consiste en que

esta operativa racionalizante [la racionalidad semiótica o narratológica] está en una relación parasitaria con respecto a una inteligibilidad de primer orden, la única capaz de establecer la mediación entre el remonte y el descenso del texto. Es esta inteligibilidad —esta inteligencia de las configuraciones narrativas - la que quisiera describir ahora en la flexión de la prefiguración y de la transfiguración del mundo de la acción, dicho de otra forma en la flexión de mímesis I y mímesis III. (Ricœur 1982, p. 57)

El autor señala una serie de rasgos de la construcción de la trama que ilustran esta inteligencia primordial; ${ }^{51}$ la construcción de la trama saca una historia de una diversidad de acontecimientos y, de modo

${ }^{49}$ Una buena parte de los primeros capítulos del segundo volumen de Ricœur 1987a desarrolla el contraste entre racionalidad narratológica (particularmente semiótica) e inteligencia (o comprensión) narrativa (véanse, por ejemplo, las pp. 33 y ss., 74 y ss., etcétera).

${ }^{50}$ En "Para una teoría del discurso narrativo" (1999b) se afirma que lo que la mímesis imita no son los acontecimientos mismos, sino su estructura lógica, su significado. La mímesis, se dice en el mismo lugar, "es una especie de metáfora de la realidad" ("Para una teoría del discurso narrativo", 1999b, p. 140).

${ }^{51}$ Véase Ricœur 1982, pp. 57-59; también 1987a, pp. 134-143. 
equivalente, transforma los acontecimientos en una historia. En segundo lugar, compone un conjunto a partir de elementos heterogéneos, ${ }^{52}$ la capacidad de seguir una historia y de contar una historia dependen de este factor. También realiza otro tipo de unificación, la de la unidad temporal, combinando sucesión e integración. La construcción de la trama posee una dimensión trascendental, pues la configuración, el acto configurante, depende de una imaginación productiva que se presta a una tipología (como la llevada a cabo por N. Frye en Anatomía de la crítica (1977)). Una tipología que, a su vez, revela un esquematismo de la función narrativa del que procede el orden categorial que el semiólogo pretende construir. ${ }^{53}$ Este esquematismo no es atemporal, sino que se constituye en una historia que tiene todos los caracteres de una tradición, definida por la dialéctica entre innovación y sedimentación que marca la producción de las obras singulares con respecto a los paradigmas históricos de construcción de la trama (las obras particulares no son simplemente manifestaciones de una gramática profunda atemporal). En Tiempo y narración, el autor subraya que los rasgos de la esquematización y la tradicionalidad (ambos con una relación específica con

${ }^{52}$ La virtualidad mediadora de mímesis II depende de la función mediadora de la trama (desde la precomprensión a la poscomprensión). En Tiempo y narración I se desarrolla la misma idea: esta función de mímesis II se realiza a través de la mediación operada por la construcción de la trama, la cual se muestra, al menos, de tres formas que convergen en una síntesis de lo heterogéneo (véase "Mímesis II" en 1987a, pp. 134-143):

1) En primer lugar, media entre la historia tomada como un todo y los acontecimientos o incidentes individuales que se integran en ella.

2) En segundo lugar, la construcción de la trama integra factores tan heterogéneos como agentes, fines, medios, interacciones, circunstancias, resultados inesperados, etc. Esta operación designa una ampliación del concepto de trama bajo la categoría de concordancia-discordancia que el autor ha desarrollado en las secciones anteriores. Este rasgo es, para Ricœur, lo que en último término constituye la función mediadora de la trama. La transición de mímesis I a mímesis II es el fruto de la actividad configurante entendida como el paso de lo paradigmático a lo sintagmático ("la narración pone de manifiesto en el orden sintagmático, todos los componentes capaces de figurar en el cuadro paradigmático establecido por semántica de la acción. Este paso [...] constituye la transición misma de mímesis I a mímesis II", p. 136).

3) Por último, la trama ejerce una función mediadora en virtud de sus rasgos temporales específicos, al extraer la configuración de la sucesión. Cierta unidad temporal se impone a la mera sucesión de los acontecimientos.

53 "Es la familiaridad con las obras, tal como aparecieron en la sucesión de las culturas de las que somos herederos, la que instruye la inteligencia narrativa, antes de que la narratología construya con ellas un simulacro intemporal" (Ricœur 1987b, p. 33).

Diánoia, vol. LI, no. 57 (noviembre 2006). 
el tiempo) "aseguran la continuidad del proceso que une mímesis III a mímesis II", al mismo tiempo que exigen más claramente que otras características el soporte de la lectura (Ricœur 1987a, p. 140). La lectura, como veremos, desempeña el papel fundamental en esta transición.

3) La lectura. Mímesis II, llevada a su inteligibilidad primera, "requiere por complemento un tercer estadio representativo que merece también ser llamado mímesis" (Ricœur 1982, p. 59).

Ricœur nos advierte contra dos peligros; por un lado, el de caer en una forma sutil de representación especular (copia, reflejo) al creer que la obra literaria "enseña lo universal", como ya había dicho Aristóteles de la poesía frente a la historia, porque es lo esencial de la acción lo que ha sido re-presentado. El segundo peligro viene de la semiótica (podríamos hacerlo extensivo a otros movimientos de teoría literaria) que al clausurar la obra en el puro texto atribuye el problema de la recepción a ámbitos extrínsecos (como los de una sociología — del mismo modo, que el trayecto inicial, el correspondiente a mímesis I, podría corresponder a una psicología-, disciplinas que, al igual que la semiótica, tienen por otra parte su uso legítimo).

Será precisamente la interpretación de mímesis II como operación estructurante, como acto de configuración la que permitirá pensar como una operación continua el paso de mímesis I a mímesis III a través de mímesis II. En primer lugar, la mímesis es, como venimos recordando, una acción que trata sobre la acción, es la acción lo que es prefigurado, configurado y refigurado. Incluso transfigurar es un hacer, y también un rehacer el mundo (operación expresamente vinculada al análisis de $\mathrm{N}$. Goodman), ${ }^{54}$ mediante un proceso en el que se lleva a cabo un incremento icónico (augmentation iconique), según expresión de François Dagognet, ${ }^{55}$ gracias al cual el mundo significa más y significa de otra forma. Pero si la acción puede obtener así una legibilidad nueva es porque ya tiene una legibilidad previa en el plano de la precomprensión, la precomprensión permite la resignificación.

La unidad de la triple mímesis depende en última instancia de una concepción que, en su perspectiva más propia, elimina los límites marcados por la frontera dentro/fuera del texto: dentro del texto, fuera en la vida, en el mundo. Es el arco vida-texto-vida el que ilumina un

\footnotetext{
${ }^{54}$ Sobre las coincidencias y diferencias con N. Goodman, véase Ricœur, "Review of Way of Worldmaking", en Valdés 2000.

${ }^{55}$ Véase también Ricœur 1986, p. 222, y 1987a, p. 157. El concepto de incremento icónico parece incorporar y precisar la elevación de sentido que caracterizaba la metáfora y la tragedia en La metáfora viva.
} 
continuo en el que se ha dejado de ver el texto como interior y la vida como exterior. ${ }^{56} \mathrm{Al}$ aceptar la idea de que la recepción de la obra forma parte de la constitución de su sentido, se despeja la vía para articular el segundo y el tercer momento de la mímesis: "El lector es el operador por excelencia que asume por su hacer — su acción de leerla unidad del recorrido entero de mímesis I a mímesis III a través de mímesis II" (Ricœur 1982, p. 53; véase también la p. 62). Es el lector (o el oyente), o más propiamente el acto de lectura, el que finalmente opera la transición de un mundo prefigurado a un mundo transfigurado por la mediación de un mundo configurado. ${ }^{57}$

Ricœur concluye apuntando hacia tres consecuencias. La primera, sobre la noción de referencia, que no es ya la de referencia descriptiva, sino que debe enriquecerse con la idea de una referencia productiva. El autor subraya "vehementemente" la apertura de todo discurso, la visión hermenéutica del lenguaje. La segunda, sobre el concepto de lo real, ¿̇lo imitado en mímesis III es todavía lo real? Claramente no es lo real como algo dado y exterior. El término real adquiere aquí una difícil polisemia cuando Ricœur responde que sí, pero que real quiere decir que la acción humana es efectivamente refigurada por el hecho de ser configurada, es decir, que denota la efectividad de la palabra, el poder del lenguaje. ${ }^{58}$ Real es todo lo que una vez prefigurado es también tansfigurado. Es necesario, pues, situarse en un punto en el que inventar y encontrar ya no se distingan. En tercer lugar, ¿puede hablarse de verdad en el nivel de mímesis III? Nelson Goodman, a pesar de su teoría de la referencia rechaza el término verdad y prefiere los de ajuste o conveniencia, pero Ricœur se pregunta por qué no abrir el concepto de verdad hasta el punto de designar también esa conveniencia. No obstante, tropezamos con la noción de verdad como adecuación y no disponemos de un concepto de verdad suficientemente amplio, pues si bien es cierto que la noción de verdad como manifestación propuesta por Heidegger viene a responder a lo que demanda la mímesis, ¿se trata aún de manifestación cuando hay producción justa (en el sentido de N. Goodman)?, ¿es posible una síntesis de ambos? Para el autor estas dificultades indican que la mímesis va por delante de nuestros conceptos de referencia, de realidad y de verdad, señalando un camino y una exigencia de pensar más.

${ }^{56}$ Véase "Mimesis et représentation" (1982), p. 61.

${ }^{57}$ La lectura actualiza la capacidad de la narración para ser seguida, acompaña el juego de innovación y sedimentación de los paradigmas presentes en la composición del texto, y, por último, completa la obra en el sentido descrito por Roman Ingarden y Wolfgang Iser (p. 62; véase también Ricœur 1987a, p. 52).

${ }^{58}$ Véase Ricœur 1982, p. 63.

Diánoia, vol. LI, no. 57 (noviembre 2006). 
Sobre la reapropiación del modelo aristotélico

La estrategia de apropiación de la poética aristotélica para llevarla más allá de la cultura griega y del ámbito para el que fue elaborada ya había sido examinada en el segundo volumen de Tiempo y narración; sin embargo, Ricœur ha vuelto a ocuparse de ella de modo más sistemático y con cierta distancia en un artículo posterior: "Relectura de la Poética de Aristóteles". 59

La pregunta que debe ser satisfecha es si la poética aristotélica puede ir más allá de las limitaciones características de su modelo trágico, y, en caso afirmativo, hasta qué punto. Para que la tríada aristotélica (poiesismythos-mímesis) pueda ser llevada a la narratividad han de darse tres condiciones que, a la vez, son tres estrategias de apropiación llevadas a cabo por Ricœur. Este aspecto estratégico de la operación de reinscripción narrativa del modelo aristotélico no fue, confiesa el autor, suficientemente atendido en Tiempo y narración (p. 146). En última instancia, el proceso depende de la posibilidad de constituir con el modelo aristotélico cierto "metagénero narrativo". Para ello, Ricœur considera que tiene "el permiso" del filósofo griego, el cual, sin embargo, en la propia cita aducida (Aristóteles 1988, 1449b17-20, p. 144) afirma "pues los elementos de la epopeya se dan también en la tragedia, pero los de ésta, no todos en la epopeya" (Valdés 2000, p. 145), indicando así una eventual irreductibilidad de la tragedia a la epopeya. Pero Ricœur se va a quedar con lo que tienen en común, particularmente, con el mythos. ${ }^{60}$

En sí misma, la mayor o menor fidelidad a Aristóteles no justifica por sí sola un reproche concluyente a la propuesta ricœuriana, el problema estriba en que nuestro autor pretende defender el rigor exegético de su reconstrucción, que considera necesario. A pesar de la aptitud de la concepción aristotélica para promover la reflexión, es posible que el celo de Ricœur por mantenerse vinculado a ella se convierta, a veces, en un lastre. Estas dificultades se manifiestan en la necesidad de elaborar una justificación como la que sigue.

59 "Relectura de la Poética de Aristóteles", Valdés 2000, pp. 139-154.

${ }^{60}$ En el capítulo 24 de la Poética, Aristóteles señala distintas diferencias entre tragedia y epopeya, como la melopeya y el espectáculo, partes de la tragedia que no se encuentran en la epopeya, la mayor extensión de ésta, con las posibilidades que ello supone, la más adecuada presencia de lo irracional, o la posibilidad, reprochable, que tiene para escapar al principio de la mímesis, y que podríamos aplicar con más amplitud a la poesía lírica ("Personalmente, en efecto, el poeta debe decir muy pocas cosas; pues, al hacer esto, no es imitador", 1460a7). Y, sobre todo, que la epopeya es un relato, lo que se excluye expresamente de la definición de tragedia. 
(1) La primera de las condiciones para la reinscripción de la tríada aristotélica en el plano de la narratividad (metagénero narrativo) es elevar el concepto de actividad configurante al grado más alto posible de formalidad, lo que se cumple gracias a la noción de concordancia discordante. La dialéctica concordancia-discordancia, en la que la discordancia está incorporada en la concordancia, se encuentra implícita en el mythos aristotélico. La naturaleza de esta dialéctica ha sido expresada por Ricœur mediante el concepto de "síntesis de lo heterogéneo". ${ }^{61}$

(2) La segunda condición concierne a la propia naturaleza de la ficción que supone la instauración de una de ruptura o suspensión con respecto a la praxis efectiva. Sólo gracias a esta distancia que la ficción instaura, la mímesis puede representar, es la misma distancia que hace de la literatura "un inmenso laboratorio de experiencias de pensamiento" (Ricœur 1987b, p. 147), experiencias que ponen a prueba diferentes maneras de componer dicha y desdicha, bien y mal, vida y muerte. La tragedia no sería más que una combinación típica de tales variaciones. La "katharsis" tiene también lugar en el espacio de la ficción, y en esta medida participa de la misma distancia o suspensión que la mímesis y el mythos, pero, al mismo tiempo, hace efectiva la posibilidad del texto para ir más allá de sí mismo. El cumplimiento de esta capacidad tiene como condición "la ficcionalización de las pasiones" en el mythos. La cuestión de la "katharsis" se convierte así en el problema de la incidencia de la ficción en la praxis, lo que incumbe a una estética de la recepción y a una teoría de la lectura determinadas, en Ricœur, por la teoría de la refiguración (mímesis III).

(3) En tercer lugar, es necesario ensamblar la narratividad con la temporalidad, coordinación que no se da en Aristóteles. Ricœur lo ha hecho partiendo de la confrontación entre la filosofía del tiempo de Agustín y la poética aristotélica, que le permitió obtener la noción de concordancia discordante en Tiempo y narración. Esta confrontación se amplió después a toda la fenomenología del tiempo y a la réplica poética ofrecida por la narración (véase Martínez 1999).

El proceso marcado por estas tres condiciones-estrategias tiene una doble finalidad, epistemológica y ontológica. La primera consiste en sacar a la luz un modo de inteligibilidad, la inteligibilidad narrativa (de la que

${ }^{61}$ Véanse las notas 32 y 52. 
nos hemos ocupado en contraste con la racionalidad narratológica), que rige una esfera del comprender como modo de reunir ocurrencias temporales; la segunda es "decir el tiempo a través del medium del acto de contar" (Ricœur 1987b, p. 149).

Lo más fácil sería quedarse aquí, en la justificación de la conversión narrativa del modelo aristotélico, pero Ricœur, como en otras ocasiones, se atreve a pensar más. En el proceso de formación del modelo narrativo ha parecido que las tres condiciones, (1) síntesis de lo heterogéneo, (2) ficcionalización y (3) temporalización, aspiraban a tener un carácter transtemporal, casi trascendental, con respecto a todo relato. Sin embargo, esta tendencia se encuentra con graves limitaciones (especialmente con la aparición de la novela) que hacen difícil la consideración del modelo aristotélico-narrativo como una invariante, cuyas variaciones serían las distintas realizaciones narrativas empíricas. La idea del autor parece ser que su modelo no tiene un valor absoluto pero sí relevante. De todos modos, repito, el problema fundamental no sería tanto la necesidad de permanecer bajo la autoridad de Aristóteles, que puede superarse así si se desea, cuanto la validez del análisis propiamente ricœuriano. De esta manera cabría separar las dos cuestiones sin someter el valor de la propuesta de Ricœur al "nexo aristotélico" en los términos por él pretendidos. Esto no supone soslayar o descuidar la relación con la Poética, sino únicamente una ventaja analítica al permitir apreciar el proyecto ricœuriano con independencia de si es realmente fiel a Aristóteles o hasta qué punto, y en qué momentos rompe con él.

Entre las limitaciones destaca la que señala el problema de la clausura en la novela contemporánea, más concretamente "el eclipse de todo criterio de clausura", al que ya nos hemos referido, ${ }^{62}$ y que ataca directamente lo que Ricœur considera el punto más sensible del modelo aristotélico: "la exigencia de que la historia contada sea una y completa" (Ricœur 2000, p. 152). ${ }^{63}$ Yendo aún más lejos, se plantea la

${ }^{62}$ Véase la nota 34.

${ }^{63}$ En Tiempo y narración II (1987b) escribía: "Sabemos que el mythos es la imitación de una acción única y completa"; por tanto, es "legítimo tomar como síntoma del fin de la tradición de construcción de la trama el abandono del criterio de totalidad y, por tanto, la intención deliberada de no terminar la obra" (p. 43). Pero cuando, en la novela contemporánea, la "crisis" ha reemplazado al "final", no significa la ausencia de todo fin, sino su transformación en un fin inmanente, un final que apela al lector, de modo que la disolución de la trama sea una señal que se le dirige para que coopere en la obra. Según Ricœur, "la frustración no puede ser la última palabra" y "es necesario que el trabajo de composición por parte del lector no se haga imposible" (p. 51). En última instancia, lo que se juega es la función de las ficciones como respuesta a la necesidad de "imprimir el sello del 
posibilidad de que lo narrativo no sea sino una figura pasajera y que, como afirmaba Benjamin, la muerte del relato ya esté en marcha.

La respuesta de Ricœur abre la contingencia de nuevas metamorfosis del relato, relativizando su propio modelo, pero niega el agotamiento de la narración, y encuentra las razones no en el lado de la producción, sino en el de la recepción del relato. En la estética de la recepción, H.R. Jauss ha establecido el vigor de las nociones de expectativa y de horizonte de expectativas; tales expectativas no sólo "obedecen —dice Ricœur- a leyes de estructuración que se resisten a la erosión de los paradigmas, sino que suscitan un reclamo de relato que parece inagotable" (1987b, p. 153). En última instancia, lo que justifica la convicción del autor respecto a la vida del relato es que el relato literario no sólo imita la acción, sino que también es una imitación de relato, en tanto que el acto de narrar ya pertenece al juego de las interacciones humanas. Es difícil ver, sin embargo, cómo la relevancia de esta actividad (la narración preliteraria que forma parte de la praxis cotidiana) puede limitarse a (o privilegiar) la perspectiva de la recepción, ya que también la producción puede encontrar un fundamento en esta imitación del relato. Narrar es una de las estructuras más estables del actuar humano, pero no sabemos si Ricœur está pensando sólo en el relato de ficción (la narratividad también se expresa en el relato histórico), pues cifra el origen de esa estabilidad en la capacidad de la ficción para poner a prueba virtualidades éticas. ${ }^{64}$

Para concluir, podemos constatar que "no tenemos la menor idea de cómo sería una cultura en la que no se supiese lo que significa contar" (Ricœur 1987b, p. 154), ${ }^{65}$ y por ello podemos esperar que, aunque se siga transformando, el acto de contar no perecerá.

orden sobre el caos, del sentido sobre el no-sentido, de la concordancia sobre la discordancia" (p. 54).

64 "Porque en el espacio de juego de la ficción, y en ningún otro, ponemos a prueba las preferencias, las evaluaciones que la ética toma a su cargo" (Ricœur 1987b, p. 153).

${ }^{65}$ En términos semejantes se expresa Tiempo y narración II (1987b): "Nada excluye, pues, que la metamorfosis de la trama encuentre en alguna parte un límite más allá del cual ya no se puede reconocer el principio formal de configuración temporal que hace de la historia narrada una historia única y completa. Y sin embargo... Y sin embargo. Quizá es preciso, pese a todo, confiar en la exigencia de concordancia que estructura aún hoy la espera de los lectores y creer que nuevas formas narrativas, cuyo nombre ignoramos todavía, están naciendo ya, que atestiguarán que la función narrativa puede metamorfosearse pero no morir. Ignoramos totalmente lo que sería una cultura en la que ya no se supiera lo que significa narrar" (p. 58).

Diánoia, vol. LI, no. 57 (noviembre 2006). 
Desde este punto de vista la narratividad expresaría un rasgo antropológico.

Mímesis y representación en las artes

Debemos tener presente que Ricœur no ha elaborado sistemáticamente este punto, por lo que necesariamente sus observaciones tendrán un carácter más disperso que en el caso de la metáfora y del relato, pero observaremos cómo se iluminan desde la concepción que acabamos de considerar. Cuestión diferente será si tal concepción es completa o directamente aplicable al ámbito de las artes más allá de la esfera literaria.

La oposición entre la noción de mímesis aristotélico-ricœuriana y la de representación, entendida como copia o reproducción, se universaliza cuando el argumento elaborado inicialmente en la investigación sobre la metáfora, y aplicada después a todo el campo literario, es confrontado con la obra de arte en general, y especialmente con la pintura y la música ${ }^{66}$ comenzando con lo que podríamos llamar la paradoja mimética, y que podría formularse como una relación inversamente proporcional entre figuración y mímesis. ${ }^{67}$ Lo primero que, de entrada y de forma más epidérmica, sorprende es que el teórico de la mímesis se incline preferentemente en sus gustos personales por el arte del siglo xx, en general por el no figurativo (o polifigurativo), y más aún que conceda a éste cierta ventaja sobre el figurativo. La mímesis es entendida fundamentalmente desde la óptica de la refiguración: la función de la refiguración es mimética, no en el sentido de reproducir lo real, sino de reestructurar el mundo del receptor. La paradoja es expresada así: "sólo cuando, ya en el siglo xx, la pintura dejó de ser figurativa pudo tenerse en cuenta la medida de esta mímesis, cuya función no es ayu-

\footnotetext{
${ }^{66}$ En ocasiones, Ricœur ha propuesto una revisión de la noción de representación a favor de una interpretación polisémica arrastrada por su concepción de mímesis productora o creadora, oponiendo entonces la pareja mímesis-representación a lo que denomina "ilusión representativa", basada en la correspondencia (verdad como adecuación) entre realidad e imagen mental (véase Ricœur 1982).

${ }^{67}$ Encontramos un matiz interesante en la diferencia que Ricœur establece entre copia y retrato, fundamental para la idea de mímesis: "Un retrato no es una copia en la medida en que es una interpretación o, mejor dicho, una búsqueda de la verdad mediante la interpretación." Y añade: "Quizá habría que decir lo mismo de la fotografía, al igual que el retrato es una configuración que pretende llevar a cabo una reconfiguración. También trata de lograr una fidelidad que se encuentra más allá de la reduplicación de la copia" (Ricœur 1999a, p. 82, n. 3).
} 
darnos a reconocer objetos, sino precisamente a descubrir dimensiones de la experiencia que no existían antes de la obra". ${ }^{68}$

Observemos que la mímesis se encuentra aquí mostrando, sobre todo, su aspecto referencial, lo que en la concepción de la triple mímesis se corresponde primordialmente con la refiguración. ${ }^{69}$

En las artes plásticas la relación entre la representación (en cuanto característica tradicional del arte figurativo) y la capacidad de la obra para irrumpir en lo real es análoga a la que se establecía entre la referencia de primer grado y la de segundo grado en el lenguaje literario: esta segunda referencia emerge gracias al ocaso de la primera; de la misma manera, la capacidad de la obra para alcanzar el mundo de nuestra experiencia aumenta, según Ricœur, a medida que se desvanece su función representativa. Por eso, la mímesis creadora, cuya función consiste en ayudarnos a descubrir nuevas dimensiones de la experiencia, sólo ha podido ser cabalmente comprendida con el desarrollo de la pintura no figurativa. La paradoja se muestra, asimismo, en que cuanto más se distancia la obra de la realidad inmediata (cfr. supra la segunda condición en la sección sobre la reapropiación del modelo aristotélico, y la teoría de la doble referencia), mayor es su poder para incidir en lo real, para reestructurarlo y modificar el mundo del receptor. ${ }^{70}$ Ricœur ofrece el ejemplo de la fotografía: la practicada por el aficionado está más cerca de la mera representación, de la reproducción; el viaje (de ida y vuelta) a la realidad es demasiado corto. Su capacidad de transformar nuestra experiencia es menor que el de la fotografía artística, en la misma medida en que ésta se libera de la simple representación/imitación.

La distinción mímesis/representación no es, sin embargo, totalmente equivalente a la que podemos realizar entre pintura no figurativa y pintura figurativa. Si el valor artístico de una obra figurativa no depende esencialmente de la calidad de la reproducción, o de la conformidad con ciertas reglas, o del parecido con el modelo, sino de algo más, de algo que excede a la representación, y que Ricœur denomina acrecentamiento (en la línea del anteriormente aparecido "incremento icónico", o la elevación de sentido que se atribuía a la metáfora), entonces la

68 "La experiencia estética", en Valdés 2000, p. 158.

${ }^{69}$ La refiguración expresa la segunda vertiente del signo, la referencial (mientras que la primera coincidiría con la configuración), e indica "la capacidad de la obra para reestructurar el mundo del lector desconcertando, contestando, remodelando sus expectativas. Califico la función de refiguración de mimética" (Ricœur 2000, p. 158.).

${ }^{70}$ Véase también la doble vertiente del signo, anteriormente mencionada. 
ruptura entre arte figurativo y no figurativo debe ser reinterpretada: mediante la representación el arte figurativo ocultaba su propia cualidad estética. ${ }^{71}$

En relación con el origen literario de la teoría, la idea fundamental sigue siendo la de la refiguración, ${ }^{72}$ ahí está el principio mimético fundamental común a la literatura, las artes plásticas y la música: rehacer el mundo, pero en un sentido que prima cada vez más la función descubridora: la función de esta mímesis es, como hemos visto, ayudarnos a descubrir nuevas dimensiones de la existencia. En la pintura abstracta se desvela plenamente que la mímesis no consiste en imitar la realidad como una réplica, sino en "hacernos descubrir, en nuestra propia experiencia, aspectos todavía desconocidos" (Ricœur 2000, p. 158). La cuestión de la verdad en el arte se inscribe también en esta función refiguradora: hay verdad de la obra de arte "en la medida en que se la designa como la capacidad para abrirse un camino en lo real, renovándolo" (p. 158), y no según la concepción de la verdad como adecuación. La idea de descubrimiento se vincula a una interpretación del efecto de la obra (refiguración) que, más allá de su significación antropológica, tiene algo de innovación o desvelamiento ontológicos. ${ }^{73}$

De modo semejante, sólo cuando la música deja de estar al servicio de un texto o de una intencionalidad exterior "dispone de su íntegro poder de regeneración o de recomposición de nuestra experiencia personal" (Ricœur 2000, p. 159), es entonces cuando se fortalece la aptitud de la música para construir el mundo en la esfera del sentir. También

71 "Se podría decir que la pintura no figurativa ha liberado lo que en realidad ya era la dimensión propiamente estética de lo figurativo" (Ricœur 2000, p. 167). Nótese la proximidad de estos planteamientos con los de las vanguardias históricas, y concretamente con el pensamiento de Malévich. La paradoja mímesis/representación evoca la oposición que Malévich estableció entre sensibilidad pura o expresada y representación. Su defensa del arte no figurativo descansa en que en éste nada es reconocible excepto la sensibilidad, el arte no objetivo es expresión de la sensibilidad pura. La objetividad es, en este sentido, un lastre. Según Malévich el valor artístico de una obra (Ricœur dirá "lo propiamente estético") no está en el virtuosismo de la representación ni en la vivacidad de la ilusión, sin embargo, esto no significa que el arte figurativo carezca necesariamente de tal valor, aunque se encuentre oculto por la representación.

72 Observemos cómo el centro de la noción de mímesis no es la configuración, sino la refiguración, la mímesis suele ser entendida tradicionalmente en la dirección realidad-obra: la obra reproduce, recoge, refleja, incorpora, la realidad, mientras que en la refiguración el proceso es, en primera instancia, inverso: de la obra a la realidad.

${ }^{73}$ La comparación con la "Estética de la recepción" se revela sugestiva en este punto (y en todo lo relativo a mímesis III). 
en la música, su capacidad refiguradora se aprecia más cuanto más se aleja de lo figurativo, de nuevo en términos de innovación o creación: "La música nos crea sentimientos sin nombre: extiende nuestro espacio emocional, nos abre una región donde pueden figurar sentimientos absolutamente inéditos"; la música construye, así, un mundo, "un mundo de esencias singulares del sentir" (p. 159.).

La noción de mímesis muestra aquí su lado más indócil. Aunque conocemos las razones del autor para seguir llamando función o relación "mímética" a esta capacidad innovadora, descubridora, y creadora no deja de producir cierta extrañeza y un punto de vacilación: ¿no se estará forzando demasiado? Lo que sí se está produciendo es una inversión de su significado más habitual, tensando una interpretación de la versión aristotélica. Mímesis designa aquí, fundamentalmente, el efecto de la obra sobre la realidad y el receptor. ${ }^{74}$

\section{Comunicación y expresión}

La presencia de la mímesis parece debilitarse cuando el círculo de la teoría literaria es desbordado por el de la estética, entonces cobran protagonismo ideas que parecen, en una primera aproximación, ajenas al pensamiento de Ricœur, y que pueden manifestar las dificultades para extender el modelo aritotélico-ricœuriano al conjunto de las artes, y en general, para acoger de forma sistemática en una misma teoría la literatura, las artes plásticas y la música (dificultades que hubieran sido menores en el caso del cine, curiosamente desatendido por el autor a pesar de su notoria especificidad mimética y su masiva relevancia refiguradora). ${ }^{75}$ Sin embargo, la noción de mood, que ahora resultará primordial, ya estaba, como hemos visto, en La metáfora vi$v a$, lo que supone cierta continuidad, y aproxima la reflexión sobre la música y las artes plásticas a la teorización de la metáfora y la poesía lírica.

${ }^{74}$ Sólo desde esta perspectiva podría entenderse la vocación universal de la estética de la mímesis, que parecía definitivamente superada por el arte del siglo Xx. Movimientos como el Body art, la abstracción pospictórica o los Nouveaux Réalistes (las acumulaciones de Arman, por ejemplo), por citar algunos casos, que parecen desafiar la función mimética, no son, sin embargo, impermeables a la categoría de refiguración. Finalmente, las limitaciones de una eventual estética de la mímesis quedarían de algún modo sobrepasadas por una hermenéutica del arco vida-obravida.

${ }^{75}$ Relevancia limitada por la frecuente trivialidad de las obras cinematográficas contemporáneas al servicio de la industria del espectáculo.

Diánoia, vol. LI, no. 57 (noviembre 2006). 
Entre las novedades encontramos que, en la confrontación mímesis/representación, la primera comienza a ser sustituida por fórmulas como "función expresiva" (Ricœur 2000, p. 161). Aparece una concepción que podríamos llamar, con reservas, comunicativo-emotivista del arte: hay una continuidad comunicativa entre la emoción en la que la obra se origina y la emoción que despierta en el receptor, aunque sea una continuidad analógica y de resonancia. La emoción ocupa ahora el lugar central de la reflexión estética, el mood es ese algo emotivo al que la obra hace justicia. Pero lo que es comunicado no es una mera emoción, en la experiencia viva y particular del artista, sino una emoción que se transforma en obra y deja de ser emoción privada, ${ }^{76}$ una experiencia que ya no es una experiencia sino una respuesta singular, artística (plano de la ficción), a la interpelación, también singular, de la experiencia. ${ }^{77}$ Esta transformación de la emoción y de la experiencia se produce mediante el incremento icónico: "La obra aumenta icónicamente la vivencia inefable, incomunicable, cerrada sobre sí misma: Este aumento icónico, en tanto que aumento, es lo que se puede comunicar" (Ricœur 2000, p. 165). Es el equivalente a la "ficcionalización" de las pasiones que se producía en la tragedia y que hacía posible la "katharsis", el equivalente a la ruptura o a la suspensión que la ficción supone, pero ahora Ricœur nos habla también de la emoción-origen, la que se da en la experiencia del artista.

Ricœur se preocupa aquí de algo que normalmente queda fuera de su interés hermenéutico: la continuidad de la secuencia autor-obrareceptor, ya que habitualmente se alinea con la tendencia crítica iniciada por el formalismo ruso y por el "new criticism", junto al rechazo de la hermenéutica romántica, que afirma la autonomía del texto

${ }^{76}$ Pessoa ha expresado esta idea con precisión poética:

O poeta é um fingidor.

Finge tão completamente

Que chega a fingir que é dor

A dor que deveras sente.

$E$ os que lêem o que escreve,

$\mathrm{Na}$ dor lida sentem bem,

Não as duas que ele teve,

Mas só a que eles não têm.
El poeta es un fingidor.

Finge tan completamente que hasta finge que es dolor el dolor que en verdad siente. $\mathrm{Y}$, en el dolor que han leído a leer sus lectores vienen, no los dos que él ha tenido, sino sólo el que no tienen.

(Versión de Ángel Crespo)

77 "La obra dice el mundo de otra manera que representándolo: lo dice iconizando la relación emocional singular del artista al mundo, lo que he llamado el mood" (Ricœur 2000, p. 167). 
(o, en su caso, de la acción) frente a la crítica biográfica o psicologísta. ${ }^{78}$ En el origen tenemos la emoción y la experiencia del autor; esta emoción se problematiza como pregunta singular que el artista ha de responder singularmente, respuesta que consiste en la obra misma, o en la determinación de la obra. Una parte de aquella experiencia será comunicable, pero no en cuanto pura experiencia, que por sí es incomunicable, sino en la obra y por la obra, mediante la adecuación de su transformación en pregunta, por un lado, y la respuesta singular del autor, por otro. Este proceso convierte la experiencia en universalizable y, así, en comunicable. Pero la comunicación es básicamente entendida como relación (por vía del incremento icónico) de emociones análogas en el origen y en el destino de la obra: "yo diría que la obra, en lo que tiene de singular, libera en la persona que la aprecia una emoción análoga a la que la ha engendrado". ${ }^{79}$ En la obra de Van Gogh que Ricœur aduce como ejemplo, lo que transmite la obra no es la iglesia de Auvers-sur-Oise, sino, más bien, la experiencia del autor. ${ }^{80}$

Sin embargo, la apelación a la experiencia se matiza cuando la atención se focaliza sobre el mood, "una manera de habitar aquí y ahora el mundo" (Ricœur 2000, p. 164), que ocupa el lugar que correspondía al "mundo del texto" en la concepción ricœuriana de la narración, la obra se refiere al mood: "es ese mood lo que puede pintarse, componerse musicalmente, o relatarse en una obra" (p. 164). Cuando la función que aquí desarrolla el mood la cumplía el mundo del texto, Ricœur escribía: lo que hay que interpretar en un texto es una proposición de mundo, de un mundo tal que yo lo pueda habitar para proyectar en él mis posibilidades más propias. ${ }^{81}$ Pero, en otras ocasiones, parece que el mood equivale al mundo de la acción sobre el que, en Tiempo y narración, se elevaba la configuración narrativa (mímesis I). El mood parece desempeñar, a la vez, las funciones de referencia (con todo su alcance ontológico), contenido y origen mundano y vivencial de la obra. Además, en estas páginas, el autor privilegia su naturaleza emocional sobre

\footnotetext{
${ }^{78}$ Véase "Le Modèle du texte: l'action sensée considérée comme un texte", Ricœur 1986, pp. 183-212, así como los artículos comprendidos en la primera parte: "Pour une phénoménologie herméneutique".

${ }^{79}$ Ricœur 2000, p. 163. Nótese que, al ocuparse de la música en su Política, Aristóteles escribe que la música imita "estados morales" y que "las imitaciones provocan sentimientos afines en los oyentes" (Política, 1430a, p. 158).

80 "Materializa en una obra visible, lo que permanece invisible, a saber, la experiencia única y probablemente alocada que Van Gogh tenía cuando la pintó" (Ricœur 2000, p. 165).

${ }^{81}$ Véase la nota 18, supra, así como Ricœur 1986, p. 115.
} 
su aspecto cognitivo. Si el mood es lo que puede pintarse, componerse o relatarse, Ricœur estaría sugiriendo un principio de unidad estética para las artes plásticas, la música y la literatura, pero las nociones de mood y mundo del texto no son intercambiables, ni subsumibles una en otra, aunque puedan coincidir en algunas de sus funciones. Se trata de una afirmación realizada en una entrevista y, lamentablemente, Ricœur no ha tratado de elaborar una estética que integrara sistemáticamente las artes en la matriz de la teoría de la mímesis generada para la literatura. Todos los elementos "discordantes" que acabamos de observar (introducción de la experiencia del artista, la función expresiva, la concepción comunicativo-emocional, la ambigüedad del mood, la relación entre figuración y mímesis), junto a la ausencia de otros aspectos, como la temporalidad, hacen que la integración con la teoría mimética del relato resulte problemática. Sin embargo, también existen rasgos comunes que podrían formar parte de una teoría del arte que Ricœur sólo ha apuntado, comenzando por una teoría de la ficción y por la capacidad del arte para hacer mundo, que pasa por sus propiedades referenciales y por el fenómeno de la refiguración.

\section{Mímesis y posibilidad}

Una mímesis reproductora, especular, supone una operación cerrada sobre un mundo cerrado; el lenguaje, el arte, se conforman a lo dado, se clausuran en función de una realidad clausurada. Por el contrario, la mímesis ricœuriana es una operación alimentada, nutrida, en el venero de lo posible (el poeta dice lo que podría suceder, según Aristóteles). La literatura, el arte, abren lo real, y descubren una realidad susceptible de ser re-creada.

\section{EPÍLOGO}

Aunque la finalidad de este trabajo es básicamente exegética, no he podido dejar de advertir los momentos más frágiles o de mencionar aquellos aspectos más discutibles a lo largo de esta lectura de la obra de Ricœur. Trataré ahora de reunir algunas de estas observaciones críticas que, como ya se vio, pueden agruparse en dos categorías: el problema de la filiación aristotélica, y la evaluación independiente de la propuesta ricœuriana en sí misma.

La bibliografía sobre la Poética de Aristóteles, incluyendo la historia de su recepción, es inmensa, y sin duda sería valiosa una investigación sobre la situación de la versión de Ricœur en el contexto de las interpre- 
taciones del libro de Aristóteles, tratando de dilucidar, también, hasta qué punto la concepción aristotélica puede ser distendida, o cuándo es rebasada por el filósofo francés. Sin embargo, en nuestra lectura la discusión crítica es secundaria y ha permanecido en segundo plano, normalmente confinada en las notas. Entre los aspectos concernientes al texto aristotélico hemos observado la tendencia de Ricœur a reducir la mímesis al modelo trágico, comenzando por la identificación de la construcción de la trama como esencia de la mímesis. Hay que admitir que el autor está pensando normalmente en la mímesis literaria, pero su uso del término descuida frecuentemente la amplitud que tiene en Aristóteles. Esta tendencia se manifiesta también cuando relaciona la metáfora con la mímesis mediante la idea de elevación, a partir de la distinción aristotélica entre comedia y tragedia. ${ }^{82} \mathrm{Si}$ bien Aristóteles privilegia este género dramático en sus reflexiones, la mímesis es un proceso más amplio, con una diversidad proporcionada a la variedad de artes y géneros miméticos. Por otra parte, para algunos autores, la poesía lírica, encaja difícilmente en el modelo de la Poética, cuando no resulta excluida. ${ }^{83}$

Uno de los puntos más controvertidos es el de la unidad de acción y de argumento, prescrita por Aristóteles, y puesta en cuestión por la narrativa contemporánea, como el propio Ricœur ha contemplado, especialmente en relación con las nociones de totalidad, fin, y cierre o clausura de la obra. ${ }^{84}$ Es cierto que las rupturas promovidas por la narrativa contemporánea no suponen el abandono de todo orden (principio básico con el que Ricœur caracterizaba el elemento más importan-

\footnotetext{
${ }^{82}$ Véase la nota 7. Con respecto a la cuestión de la elevación, recordemos que, según Aristóteles, el poeta (como el pintor, etc.,) puede representar las cosas como son, además de como eran o como deben ser, esto podría hacer dudar de la fidelidad de la interpretación de Ricœur (en tanto que la mímesis de las cosas como son o como eran no tiene porqué implicar "elevación"), quien, en cualquier caso, acaba entendiendo la elevación como mero incremento de sentido en general, no necesariamente asociado a "lo noble" aristotélico (véase la nota 9). Que toda obra de arte suponga $\mathrm{u}$ ofrezca un incremento de sentido significa que la elevación puede concebirse también de manera negativa al señalar la obra lo absurdo del mundo o la inutilidad de la vida (o aquello que el filósofo griego consideraría indigno de la tragedia), y producir en el lector los efectos correspondientes.

${ }^{83}$ Véase López Eire 2002, pp. 85-139.

${ }^{84}$ Parecería que Azorín está pensando en Aristóteles cuando escribe, a propósito de un autor no precisamente de intención experimental (Pío Baroja): "los personajes desfilan por delante de vosotros sin que sepáis quiénes son, de dónde vienen, adónde van; las escenas suceden a las escenas en una aparente incongruencia; no hay en todo el libro ni comienzo, ni apogeo, ni desenlace, ni concierto, ni método..." (Azorín 1970, p. 93).
} 
te de la mímesis trágica, el mythos, en La metáfora viva), ni la abolición de cualquier "convención de composición", sino el avance hacia convenciones más complejas y sutiles. Pero entre la "inimaginable" ausencia de toda configuración y el canon aristotélico existe una distancia considerable en la que caben distintas fórmulas cada vez más alejadas de la unidad de acción, lo que significa que la mera existencia de cierta configuración o de cierta convención de composición no es equiparable al modelo de la Poética. Algo semejante ocurre cuando en la búsqueda de una máxima generalidad que permita acceder a un metagénero narrativo, partiendo de las proposiciones aristotélicas, los criterios formales de síntesis de lo heterogéneo y concordancia-discordante llegan a ser tan "generales" que se alejan de la concepción de la mímesis del filósofo griego, hasta el punto que la filiación, sin ser negada, queda como vaciada o desactivada. Lo que no impide que los análisis correspondientes a tales nociones resulten, en sí mismos, sugerentes y fecundos.

El nexo esencial entre Aristóteles y Ricœur radica en el rechazo de la mímesis como copia o reproducción, a partir de ahí nuestro autor desarrolla, bajo la inspiración del estagirita, la capacidad productiva de la mímesis, que se adentra en distintos trayectos de su obra, tejiendo una red que comunica buena parte de la misma. De esa capacidad dan cuenta la exploración del poder heurístico de la ficción, así como las nociones de innovación semántica, de redescripción y de refiguración. De esta manera, el autor construye una teoría de la ficción (entendiendo ésta en un sentido amplio) que se compromete con su aspecto referencial y contribuye a dilucidar sus consecuencias extralingüísticas. Independientemente de sus aportaciones en campos tan diversos como la narratología, la fenomenología del tiempo o la ética, la mímesis ricœuriana ha contribuido a comprender la naturaleza de la ficción (en especial del relato literario) y la relación que mantenemos con ella, conservando, al mismo tiempo, viva la interpelación de su eficacia ontológica.

\section{BIBLIOGRAFÍA}

Aristóteles, 1988 [1974], Poética, trad. García Yebra, Gredos, Madrid. [Versión francesa mencionada de J. Hardy, Les Belles Letres, París, 1969.]

Aristóteles, 1983, Política, trad. Julián Marías y M. Araujo, Centro de Estudios Constitucionales, Madrid.

Azorín, José Martínez Ruiz, 1970, Tiempos y cosas, Salvat y Alianza Editorial, Madrid.

Frye, Northrop, 1977, Anatomía de la crítica: Cuatro ensayos, trad. Edison Simons, Monte Ávila, Caracas. 
López Eire, A., 2002, Poéticas y retóricas griegas, Síntesis, Madrid.

Martínez Sánchez, A., 1999, “Tiempo, historia y acción”, Daimon, no. 18, Murcia, pp. 123-133.

Ricœur, P., 2003, La memoria, la historia, el olvido, trad. Agustín Neira, Trotta, Madrid.

— 2000 , “La experiencia estética”, en Valdés 2000, pp. 155-173.

_, $1999 \mathrm{a}$, La lectura del tiempo pasado: memoria y olvido, trad. Gabriel Aranzueque, Arrecife/UAM Ediciones, Madrid.

— 1999b, "Para una teoría del discurso narrativo", Historia y narratividad, trad. Gabriel Aranzueque, Paidós, ICE/UAB, Barcelona, pp. 83-156.

— 1997 , Autobiografía intelectual, trad. Patricia Willson, Nueva Visión, Buenos Aires.

——, 1996a, Tiempo y narración III, trad. Agustín Neira, Siglo XXI, México.

—, $1996 b$, Sí mismo como otro, trad. Agustín Neira, Siglo XXI, México/Madrid.

— 1995 , Teoría de la interpretación. Discurso y excedente de sentido, trad. Graciela Monges, Siglo XXI, México/Madrid.

—_ 1991a, "Poetry and Possibility", en Valdés 1991, pp. 448-462 [artículo publicado inicialmente en The Manhattan Review en 1982].

—, 1991 b, "Review of Way of Worldmaking", en Valdés 1991, pp. 200-215 [originalmente publicado en 1980 en la revista Philosophy and Literature].

— 1 1987a, Tiempo y narración I, trad. Agustín Neira, Cristiandad, Madrid.

$\longrightarrow, 1987 b$, Tiempo y narración II, trad. Agustín Neira, Cristiandad, Madrid.

_ 1986, Du texte à l'action, Seuil, París.

__, 1982, "Mimesis et représentation", Actes du XVIII Congrès des Sociétés de Philosophie de langue française (Estrasburgo, 1980), Association des Publications près les Universités de Strasbourg/Librairie Vrin, París, 1982, pp. 5163.

—_, 1980, La metáfora viva, trad. Agustín Neira, Cristiandad, Madrid.

_ 1977 , "La Structure symbolique de l'action", Actes de la 14 Conférence internationale de sociologie des religions (Estrasburgo, 1977), Secrétariat C.I.S.R., Lille, pp. 29-50.

— 1969, Le Conflit des interprétations, Seuil, París.

Valdés, Mario J. (coord.), 2000, Con Paul Ricœur, Azul Editorial, Barcelona [Monte Ávila Editores, 1998].

- (comp.), 1991, A Ricour Reader. Reflection and Imagination, Harvester Wheatsheaf, Hertfordshire (Canadá).

Recibido el 11 de mayo de 2005; aceptado el 4 de mayo de 2006. 